\title{
Nitrogen Distribution Pattern of African Yam Bean (Sphenostylis stenocarpa) exposed to Cadmium stress
}

\author{
1,2OHANMU, EO; ${ }^{2}$ IKHAJIAGBE, B; ${ }^{2}$ EDEGBAI, BO \\ ${ }^{I}$ Department of Plant Biology and Biotechnology, Edo University, Iyamho, Nigeria \\ ${ }^{2}$ Environmental Biotechnology and Sustainability Research Group, Department of Plant Biology and Biotechnology, \\ University of Benin, Nigeria \\ *Corresponding Author E-mail: edos.ricky@yahoo.com,Tel: +2347084059346
}

\begin{abstract}
In Nigeria, S. stenocarpa is an under-utilized leguminous crop grown in Edo State mainly for its tuberous root and less for the seeds. The purpose of this study was to determine the nitrogen assimilation and distribution pattern of S. stenocarpa exposed to cadmium stress by partitioning the plant accessions into root and leaf, and N-nitrate and $\mathrm{N}$-ammonia analysis was carried out during the seedling and flowering stage. The results showed that cadmium stress increased percentage foliar total nitrogen in TSs-91 in the Cd-5ESV from $2.03 \%$ to $2.03 \%$ and $1.93 \%$ to $5.73 \% 6$ and 18 weeks after sowing with increased cadmium concentration. However, there was a reduction in leaves Nitrate-N with increase in cadmium concentration. TSs-93 in Cd-5ESV had a Nitrate- $\mathrm{N}$ of $703.84 \mathrm{ppm}$ as compared to $968.14 \mathrm{ppm}$ in control while the root was significantly reduced from 771.71 to $516.36 \mathrm{ppm}$. Irrespective of leaves, roots and metal concentration, TSs-91 sow in control soils assimilated $6.29 \%$ nitrogen nitrate as compared to $0.16 \%$ in nitrogen ammonia. It was observed that the plants assimilated nitrogen more in the nitrate form than in the ammonia form and are stored in the leaves as compared to the roots except TSs-95 which stored more N-nitrate in the roots.
\end{abstract}

\section{DOI: https://dx.doi.org/10.4314/jasem.v22i7.10}

Copyright: Copyright $\odot 2018$ Ohanmu et al. This is an open access article distributed under the Creative Commons Attribution License (CCL), which permits unrestricted use, distribution, and reproduction in any medium, provided the original work is properly cited.

Dates: Received: 16 May2018; Revised: 19 June: 2018; Accepted: 10 July 2018

Keywords: legumes, nitrogen, ammonia, pollution, Nigeria, heavy metal, assimilation

Soil as a dynamic component of terrestrial ecosystem is essential for the growth of plants with a constant short term fluctuation such as variation in moisture status, $\mathrm{pH}$ and also undergo gradual alterations in response to changes in management and environmental factors (Zauro et al., 2013). However, Soil pollution may result from the accumulation of heavy metals and metalloids such as lead, cadmium, mercury and nickel, resulting from industrialization and urbanization. This heavy metal increase over time in soil and creates a serious environmental contamination problem to the natural ecosystem. The distribution of heavy metal in soils and sediments indicates the potential harm to the environment through their chemical associations since a buildup of heavy metals at high concentration can cause serious risk to human health when food plants are consumed. Cadmium $(\mathrm{Cd})$ is one of the most toxic pollutants found in the air, water, and soil, and is nonessential for plants (Fan Zhang et al., 2014). Cd has a negative influence on photosynthetic, respiratory, and nitrogen (N) metabolism in plants, resulting in a poor growth and low biomass (Sanita and Gabbrielli 1999; Pereira et al. 2006). Of Recent, Cd pollution has become more severe and has accelerated the environment deterioration, including the degradation of farmlands in the core polluted regions of the world.

There are a number of natural and anthropogenic processes which add $\mathrm{Cd}$ to soils and waters. Natural sources include volcanic eruptions but the amount of $\mathrm{Cd}$ released is usually small in comparison to manmade sources. The latter include wastes from factories, cement manufacturing, waste incineration, fossil fuel combustion, sewage sludge, phosphate fertilizers and most importance, nonferrous mining, especially $\mathrm{Pb}$ and $\mathrm{Zn}$ mining, which is the biggest input source of $\mathrm{Cd}$ to soils. In Nigeria the major source of cadmium into the soil is through fertilizers application, fumes from automobiles and compost. Moradi et al (2005) stated that naturally, about 10000 tons of cadmium is been deposited into the earth crust annually. Cadmium has received great attention in soil science and plant nutrition mainly due to its phytotoxic impact ranging from growth reduction, wilting, and chlorosis to cell death (Gallego et al., 2012).

African yam bean (Sphenostylis stenocarpa Hochst ex. A. Rich.) Harms are an underutilized tropical African tuberous legume mainly cultivated in West Africa. In 
Nigeria, it is cultivated in Edo State mostly for its seeds than tubers. The seeds are high in vitamin $\mathrm{C}$, dietary fiber, vitamin B6, potassium, and manganese (Utter, 2007). The AYB tubers are regarded as an important source of starch and protein in tropical Africa, and the plant is potentially important as a pulse legume (Busson, 2001). The amino acid content of the protein is similar to that of the soybean, though rather higher in histidine and iso-leucine. The ability to fix atmospheric nitrogen makes it an excellent component within the various farming systems because they provide residual nitrogen and reduce the needs for mineral nitrogen fertilizers by associated non-legumes such as cassava and yam. Africa is the center of diversity of the genetic resource of AYB spanning from the west through to the east and southern parts (Genetic Resources Information Network, 2009).

Although plant growth, chlorophyll content, stomata opening, transpiration, and photosynthesis have been reported to be inhibited by $\mathrm{Cd}$ in nutrient solutions (Baryla et al. 2001), there have also been reports that Cd treatments had no effect on photosynthesis or growth (Li et al., 2005) and that $\mathrm{N}$ was possibly a bioactive signaling molecule in plant responses to heavy metal stress (Arasimowicz and FloryszakWieczorek 2007). However, despite all these studies, there is no report on nitrogen assimilation and distribution pattern in AYB to Cd stress as this remain unknown. Hence, this study aimed to determine the effects of $\mathrm{Cd}$ on nitrogen assimilation and distribution pattern from roots and leaves.

\section{MATERIALS AND METHODS}

Seed: AYB accessions were procured from the International Institute of Tropical Agriculture (IITA), Ibadan, Nigeria. They are: TSs-92, TSs-91, TSs-93, TSs-94 and TSs-95.

Metal: Cadmium was procured as a solid crystal substance in the form of Cadmium Chloride $\left(\mathrm{CdCl}_{2}\right)$ from Pyrex Chemical Laboratory, Benin City, Nigeria.

Soil Collection and Land Preparation: The experiment was carried out in the Botanical garden of Plant Biology and Biotechnology, University of Benin, Benin city. The soils were collected from ten different points at the botanical garden, where the experiment was carried out in the Department of Plant Biology and Biotechnology, University of Benin, Benin City. The samples were randomly collected from the site at $0-30 \mathrm{~cm}$ depths using a soil auger. The soils were polluted with cadmium in the form of $\mathrm{CdCl}_{2}$ using $0 \mathrm{ESV}, 2.5 \mathrm{ESV}$ and 5ESV (Ecological screening value). The soil samples were made into a composite sample, air-dried and grind to pass through a $2 \mathrm{~mm}$ sieve before subjecting to physicochemical analysis according to standard procedures.

Table 1: Treatment designations for metal concentrations

\begin{tabular}{llc}
\hline Treatment & Description & Replications \\
\hline 0 ESV & Control (unpolluted soil) & 3 \\
$2.5 \mathrm{ESV}$ & $0.15 \mathrm{~g}$ of cadmium chloride diluted in 2L of water and mixed in 15kg soil & 3 \\
$5 \mathrm{ESV}$ & $0.30 \mathrm{~g}$ of cadmium chloride diluted in 2L of water and mixed with 15kg soil & 3 \\
\hline \multicolumn{2}{c}{ ESV - Ecological screening value $(4 \mathrm{mg} / \mathrm{kg}$ ) (Efroymson, 1997) }
\end{tabular}

$\% \mathrm{~N}=\frac{\text { Instrument. Reading. } \mathrm{X} \text { Slope Reciprocal X Color Vol. X Digest Vol. }}{\text { Weight of Sample X Aliquot Taken X } 10000}$
$\mathrm{NH}, \mathrm{N}(\mathrm{PPM})=\frac{\text { Instrument. Reading. X Slope Reciprocal X Color Vol. X Digest Vol. }}{\text { Weight of Sample X Aliquot Taken }}$
$\mathrm{NO}_{3} \mathrm{~N}(\mathrm{PPM})=\frac{\text { Instrument. Reading. X Slope Reciprocal X Color Vol. X Digest Vol. }}{\text { Weight of Sample X Aliquot Taken }}$
$\%$ NAssimilated as Nitrate $=$ Nitrate nitrogen $\div$ total nitrogen $(\mathrm{ppm}) \times 100$
$\%$ NAssimilated as A mononia $=$ Ammonium nitrogen $\div$ total nitrogen $(\mathrm{ppm}) \times 100$

Nitrogen assimilatory responses: Total nitrogen contents of plants leaves and roots were determined at seedling and flowering stage. Concentrations of Total Nitrogen, Ammonia-N and Nitrate-N were also determined. The proportion of the total $\mathrm{N}$ uptake acquired as nitrate and ammonium were subsequently determined as percentages (AOAC, 2005). The $\mathrm{f}$ formula used for computation of percentage nitrogen, ammonium nitrogen, nitrate nitrogen, nitrogen assimilated as nitrate and ammonia are shown above.

Data Analysis: The data were subjected to analysis of variance (ANOVA) and least significant difference (LSD) was used to separate any significant differences 
between their mean. The SPSS $-20^{\circledR}$ software was used to run analyses of data.

\section{RESULTS AND DISCUSSIONS}

Percentage Total Nitrogen Composition: The effects of cadmium pollution on percentage nitrogen composition of Africa yam bean accessions (TSs-91, TSs-92, TSs-93, TSs-94 and TSs-95) is presented below (Fig 1). Cadmium pollution resulted to increased foliar total nitrogen percentage in all treatments as compare to control 6 weeks after sowing (WAS). TSs-91 in the Cd-5ESV had a $4.8 \%$ foliar TN as compared to $2.03 \%$ in control. The effects of environmental stresses on plants are determined by the responses of the individual cells in which the integrity of structure and function is affected (Ciamporova and Mistrik, 1993). Cadmium toxicity also resulted to an increase in percentage foliar and root TN with increase in the metal concentration 18 WAS. Take for instance, cadmium pollution resulted in a $5.73 \%$ foliar $\mathrm{TN}$ of TSs-93 in Cd-5ESV as compared to $1.93 \%$ in control. Nitrogen is the limiting nutrient in several salt marshes (Valiela and Teal, 1979; Delaune and Patrick, 1980). After 18WAS, it was observed that percentage TN of TSs-92 and 93 were more in the root than the leaves while for TSs-91, 94 and 95 the reverse was the case. However, cadmium pollution had no significant differences on total nitrogen percentage of the studied accessions at $\mathrm{P}=0.10$.

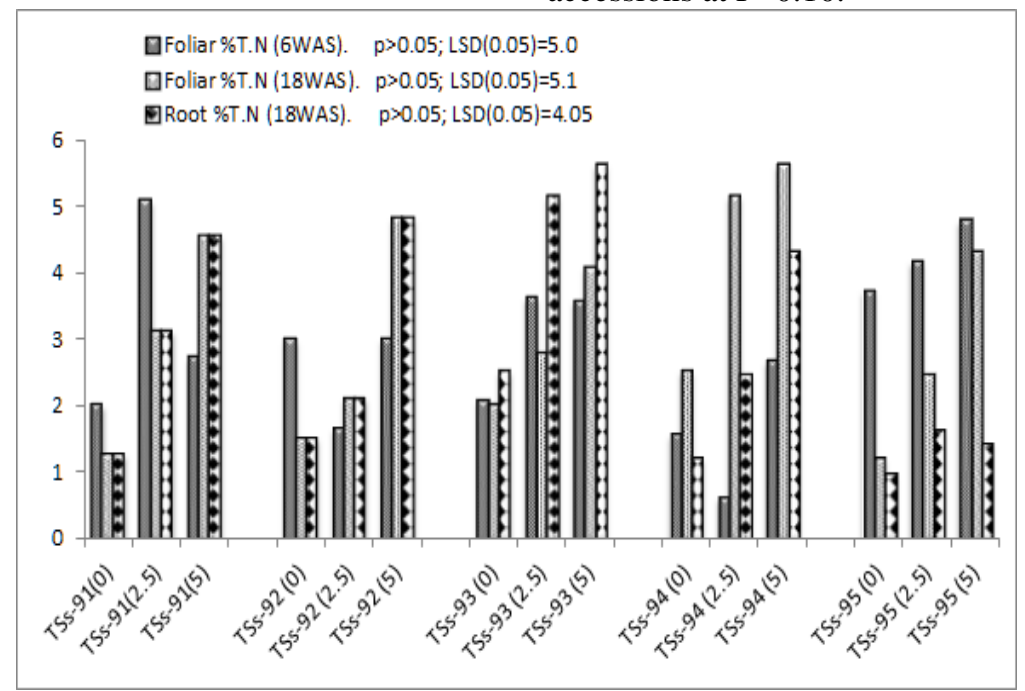

Fig 1: Percentage total nitrogen composition of Africa yam bean accessions exposed to Cd pollution

Nitrogen Composition and Distribution in Nitrate- $N$ and Ammonium- $N$ : The exposure of nitrogen composition in Africa yam bean accessions (TSs-91, TSs-92, TSs-93, TSs-94 and TSs-91) to cadmium is present below (Table 2). There was a reduction in the leaves Nitrate-N with increase in cadmium concentration. TSs-93 in Cd-5ESV had a Nitrate-N of $703.84 \mathrm{ppm}$ as compared to $968.14 \mathrm{ppm}$ in control with the highest difference of $490.73 \mathrm{ppm}$ between the Cd-5ESV and control of TSs-91. The nitrogen was distributed in both ammonia and nitrates form in leaves and root respectively. However, the legumes crops assimilated nitrogen more in the Nitrate- $\mathrm{N}$ form than Ammonia-N both in the leaves and root and differs across accessions. However, there was no significant difference at $\mathrm{P}=0.086$. In Ammonia-N composition, cadmium exposure resulted in invariability in composition with increase in the concentration. Take for instance, TSs-91 reduced from 19.83 to $15.11 \mathrm{ppm}$ in Cd-2.5ESV and later increased to $17.06 \mathrm{ppm}$ in Cd-5SV while in TSs-95, Ammonia$\mathrm{N}$ reduced from 37.33 to $18.43 \mathrm{ppm}$ with increase in the metal concentration between the Cd-5ESV and control. Hence there was a significant difference at $\mathrm{P}=0.011$. Incidence of metal raised nitrogen levels in the leaves both 6 and 18 weeks after sowing in all plants types and accessions when compared with control. Plants assimilated nitrogen in both leaves and roots as ammonia, nitrates and other forms. Roots are the first plant organs that impose and get into contact with HMs polluted environments. However, Nitrate-N accumulation in both leaves and roots significantly differed across plant types and accessions. For example, TSs accessions assimilated more nitrate in the leaves than the root whereas TSs-95 assimilated more nitrate in the roots than the leaves (AYB). The root Nitrate-N composition also followed similar trend of reduced with increase in the cadmium concentration as compared to the control resulting in the highest Nitrate-N difference of $295.77 \mathrm{ppm}$ between the Cd$5 \mathrm{ESV}$ and control of TSs-92. Hence there was a significant difference at $\mathrm{P}=0.001$. Nitrate-N was more distributed in the leaves than the root irrespective of treatment and accession type except in TSs-95. For 
example, the Nitrate- $\mathrm{N}$ distribution in the leaves of TSs-93 was $968.14,936.75$ and $703.84 \mathrm{ppm}$ as compared to the $771.71,707.83$ and $516.36 \mathrm{ppm}$ in the root of control, Cd-2.5ESV and Cd-5ESV respectively.

Percentage nitrogen assimilated as nitrate or ammonium: The effects of cadmium pollution on percentage nitrogen assimilated as nitrate in the leaves of Africa yam bean accessions (TSs-91, TSs-92, TSs93, TSs-94 and TSs-95) is presented below (Table 3). Cadmium pollution resulted in the highest difference of $5.61 \%$ foliar $\mathrm{N}$-assimilated as nitrate in TSs-91 as compared to $1.70 \%$ in TSs-94. Other accessions also followed similar trend of reduction in foliar percentage $\mathrm{N}$-assimilated as nitrate with increase in the metal concentration. However, cadmium pollution has no significant difference at $\mathrm{P}=0.882$. The excessive uptake of nonessential bivalent cations to the aerial plant parts shifts its cellular phosphorylation state, eliciting oxidative stress and a range of physiological disturbances. The percentage foliar $\mathrm{N}$-assimilated as ammonia of AYB accessions to cadmium exposure has been reported. Cadmium exposure reduced the $\% \mathrm{~N}$-assimilated as ammonia from $0.31 \%$ to $0.04 \%$ and $0.39 \%$ to $0.13 \%$ in the leaves and root of TSs-95. However, there was no significant difference $(\mathrm{P}=0.456 ; 0.062)$ on $\% \mathrm{~N}$-assimilate as ammonia in TSs accessions to cadmium exposure. The accessions assimilated more nitrogen in the nitrate form in their leaves irrespective of accession type or treatment. However, TSs- 95 divers by assimilating more nitrate in the root $(16.63 \%, 9.99 \%$ and $9.08 \%)$ as compared to $5.05 \%, 2.185$ and 1.875 in leaves.
Table 2: African yam bean nitrogen composition and distribution in Nitrate-N and Ammonium-N 18 weeks after sowing

\begin{tabular}{|c|c|c|c|c|c|}
\hline $\begin{array}{l}\text { Plant } \\
\text { Accessions }\end{array}$ & $\begin{array}{l}\text { Cd. Conc. } \\
\text { (ESV) }\end{array}$ & $\begin{array}{l}\text { Nitrate- } \\
\text { Nitrogen } \\
\text { (ppm) }\end{array}$ & $\begin{array}{l}\text { Ammonia- } \\
\text { Nitrogen } \\
(\mathbf{p p m})\end{array}$ & $\begin{array}{l}\text { Nitrate- } \\
\text { Nitrogen } \\
\text { (ppm) }\end{array}$ & $\begin{array}{l}\text { Ammonia- } \\
\text { Nitrogen } \\
\text { (ppm) }\end{array}$ \\
\hline \multirow{4}{*}{ TSs-91 } & & \multicolumn{2}{|c|}{ Leaves } & \multicolumn{2}{|c|}{ Root } \\
\hline & 0 & 798.91 & 19.83 & 438.90 & 13.84 \\
\hline & 2.5 & 513.11 & 15.11 & 303.32 & 11.51 \\
\hline & 5 & 308.18 & 17.06 & 243.12 & 9.36 \\
\hline \multirow[t]{3}{*}{ TSs-92 } & 0 & 611.45 & 22.23 & 397.12 & 16.18 \\
\hline & 2.5 & 506.33 & 23.46 & 178.42 & 15.13 \\
\hline & 5 & 211.84 & 21.83 & 101.45 & 14.12 \\
\hline \multirow[t]{3}{*}{ TSs-93 } & 0 & 968.14 & 19.15 & 771.71 & 17.15 \\
\hline & 2.5 & 936.75 & 21.78 & 707.83 & 15.78 \\
\hline & 5 & 703.84 & 15.85 & 516.36 & 10.85 \\
\hline \multirow[t]{3}{*}{ TSs-94 } & 0 & 740.96 & 35.62 & 690.17 & 29.33 \\
\hline & 2.5 & 703.43 & 30.15 & 678.10 & 24.86 \\
\hline & 5 & 698.80 & 25.54 & 556.82 & 22.07 \\
\hline \multirow[t]{3}{*}{ TSs-95 } & 0 & 611.35 & 37.33 & 1596.03 & 32.98 \\
\hline & 2.5 & 536.15 & 35.60 & 1619.00 & 27.11 \\
\hline & 5 & 803.51 & 18.43 & 1289.16 & 11.71 \\
\hline $\mathrm{P}$-value & & 0.086 & 0.011 & 0.000 & 0.001 \\
\hline Sig* & & $\mathrm{P}>0.05$ & $\mathrm{P}<0.01$ & $\mathrm{P}=0.000$ & $\mathrm{P}<0.01$ \\
\hline
\end{tabular}

Table 3: African yam bean percentage nitrogen assimilated as nitrate or ammonium 18 weeks after sowing

\begin{tabular}{|c|c|c|c|c|c|}
\hline $\begin{array}{l}\text { Plant } \\
\text { Accessions }\end{array}$ & $\begin{array}{l}\text { Cd. } \\
\text { Conc. } \\
\text { (ESV) }\end{array}$ & $\begin{array}{l}\% \mathrm{~N} \\
\text { assimilated } \\
\text { as Nitrate }\end{array}$ & $\begin{array}{l}\% \mathrm{~N} \\
\text { assimilated } \\
\text { as ammonia }\end{array}$ & $\begin{array}{l}\% \mathbf{N} \\
\text { assimilated } \\
\text { as Nitrate }\end{array}$ & $\begin{array}{l}\% \mathbf{N} \\
\text { assimilated } \\
\text { as ammonia }\end{array}$ \\
\hline \multirow{4}{*}{ TSs-91 } & & \multicolumn{2}{|c|}{ Leaves } & \multicolumn{2}{|l|}{ Roots } \\
\hline & 0 & 6.29 & 0.16 & 3.46 & 0.11 \\
\hline & 2.5 & 1.64 & 0.05 & 0.97 & 0.04 \\
\hline & 5 & 0.68 & 0.04 & 0.53 & 0.02 \\
\hline \multirow{3}{*}{ TSs-92 } & 0 & 4.02 & 0.15 & 2.61 & 0.11 \\
\hline & 2.5 & 2.40 & 0.11 & 0.85 & 0.07 \\
\hline & 5 & 0.44 & 0.05 & 0.21 & 0.03 \\
\hline \multirow{3}{*}{ TSs-93 } & 0 & 4.82 & 0.010 & 3.06 & 0.08 \\
\hline & 2.5 & 3.37 & 0.08 & 1.37 & 0.04 \\
\hline & 5 & 1.73 & 0.039 & 0.92 & 0.03 \\
\hline \multirow{3}{*}{ TSs-94 } & 0 & 2.94 & 0.14 & 6.12 & 0.29 \\
\hline & 2.5 & 1.36 & 0.06 & 2.86 & 0.12 \\
\hline & 5 & 1.24 & 0.06 & 1.20 & 0.08 \\
\hline \multirow{3}{*}{ TSs-95 } & 0 & 5.05 & 0.31 & 16.63 & 0.39 \\
\hline & 2.5 & 2.18 & 0.14 & 9.99 & 0.22 \\
\hline & 5 & 1.87 & 0.04 & 9.08 & 0.13 \\
\hline P-value & & 0.882 & 0.456 & 0.001 & 0.062 \\
\hline Sig* & & $\mathrm{P}>0.05$ & $\mathrm{P}>0.05$ & $\mathrm{P}=0.000$ & $\mathrm{P}>0.05$ \\
\hline
\end{tabular}

Conclusion: Cd toxicity reduced the total nitrogen assimilation of $\mathrm{S}$. stenocarpa accessions. Nitrogen is ready available for the plants use in the $\mathrm{N}$-nitrate form than the $\mathrm{N}$ ammonia form and stored in the leaves except for TSs-95. Recommendations are made for TSs-95 to be cultivated in Edo state in marginal soil so has to boost the soil fertility and enrich the soil with nitrogen. The phytotoxicity of $\mathrm{Cd}$ in the tubers of TSs-95 should be investigated to ascertain if edible for consumption.

Acknowledgement: I express my sincere thanks to my mom, Late Dr. O.K. Ohanmu for her financial support during the course of this research work.

\section{REFERENCE}

A.O.A.C. (2005). Association of Official Analytical Chemist 972, 25 Codex General Method.

Arasimowicz, M; Floryszak, WJ (2007). Nitric oxide as a bioactive signaling molecule in plant stress responses. Plant Sci, 172:876-887.

Baryla, A; Carrier, P; Franck, F; Coulomb, C; Sahut, C; Havaux, M (2001). Leaf chlorosis in 
oilseed rape plants (Brassica napus) grown on cadmium-polluted soil: causes and consequences for photosynthesis and growth. Planta 212: 696709.

Ciamporova, M; Mistrik, I. (1993). The ultrastructural response of root cells to stressful conditions. Environ Exp Bot, 33: 11 - 26.

Delaune, RD; Patrick, WH (1980). Nitrogen and phosphorus cycling in a Gulf Coast salt marsh. Estuarine perspect. [Proc. Bienn. Int. Estuarine Res.Conf.], $5^{\text {th }} 1979$ pp. $153-162$.

Efroymson, RA; Will, ME; Suter, GW (1997). Toxicological bench mark for contaminants of potential concern for effects on soil and litter invertebrates and heterotrophic process: 1997 revision. ES/ER/TM-126/R2. Oak Ridge National Laboratory, US Department of Energy, Oak Ridge, TN.

Gallego, SM; Pena, LB; Barcia, RA; Azpilicueta, CE; Iannone, MF; Rosales, EP (2012).

Unravelling cadmium toxicity and tolerance in plants: in sight in to regulatory mechanisms. Environ Exp Bot, 83: 33-46.

GRIN (2009). Genetic Resources Information Network (GRIN). GRIN Taxonomy for Plants. http://www.ars-grin.gov/cgibin/npgs/html/taxon.pl?35250\#dist. (5 February2010).
Li, Z; Li, L; Chen, GPJ (2005). Bioavailability of Cd in a soil-rice system in China: soil type versus genotype effects. Plant Soil, 271: 165-173.

Moradi, A; Abbaspour, KC; Afyuni, M (2005). Modelling field-scale cadmium transport below the root zone of a sewage sludge amended soil in an arid region in Central Iran. J Cont Hydro, 79: 187-206.

Pereira, SIA; Lima, AIG; Figueira, EMAP (2006) Heavy metal toxicity in Rhizobium leguminosarum biovar viciae isolated from soils subjected to different sources of heavy metal contamination: effect on protein expression. Appl. Soil Ecol, 33:286-293

Sanita, TL; Gabbrielli, R (1999). Response to cadmium in higher plants. Environ Exp Bot, 41:105-130.

Valiela, I; Teal JM (1974). Ecology of Halophytes eds Reimold, R. J. and Queen, W. H.) Academic, New York, 543-563.

Zauro, SA; Dabai, MU; Tsafe, AI; Umar, KJ; Lawal, AM (2013). Extent of someheavy metals contamination in soil of farmlands around Sokoto Metropolis. J Euro. Sci. 9 (3):30 - 36. 